\title{
Microcirculatory alterations are more severe in anemic than in ischemic hypoxia
}

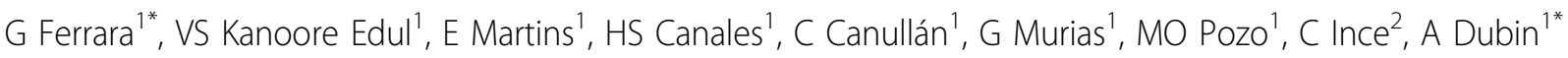 \\ From ESICM LIVES 2015 \\ Berlin, Germany. 3-7 October 2015
}

\section{Introduction}

The intestinal mucosal-arterial $\mathrm{PCO}_{2}\left(\Delta \mathrm{PCO}_{2}\right)$ remains remarkably stable in anemic hypoxia suggesting that the villi perfusion is well-maintained ${ }^{1}$. The microcirculation, however, has been insufficiently studied in extreme hemodilution.

\section{Objectives}

To assess intestinal microcirculation during progressive hemorrhage and hemodilution.

\section{Methods}

Sheep were assigned to either stepwise bleeding $(\mathrm{n}=8)$ or blood exchange with HES 130/0.4 $(\mathrm{n}=8)$. A sham group $(\mathrm{n}=8)$ was also studied. Oxygen transport and consumption were measured by expired gases analysis, microcirculation with SDF-technology, and $\triangle \mathrm{PCO}_{2}$ by air capnometry.

\section{Results}

In the last step, there were similar reductions in systemic and intestinal oxygen transports and consumptions, and increases in respiratory quotient and lactate, in ischemic and anemic hypoxia compared to sham group. $\triangle \mathrm{PCO}_{2}$ only increased in ischemic hypoxia $(25 \pm 10,5 \pm 6$, and 5 $\pm 6 \mathrm{~mm} \mathrm{Hg}, P<0.01$ ). Superior mesenteric artery blood flow decreased in ischemic hypoxia and increased in anemic hypoxia $(138 \pm 55,524 \pm 99$, and $325 \pm 112 \mathrm{~mL} / \mathrm{min}$, $P<0.0001$ ), but mucosal and serosal microcirculations were more severely altered in anemic than in ischemic hypoxia.

\section{Conclusions}

Although intestinal serosal and mucosal microcirculations were severely compromised in anemic hypoxia, the $\triangle \mathrm{PCO}_{2}$ did not increase. The lack of change in $\triangle \mathrm{PCO}_{2}$ cannot be ascribed to the preservation of villi perfusion. These findings might be explained by blood flow redistribution toward submucosal and muscular layers.

\section{Grant Acknowledgment}

Supported by the grant PICT-2010-00495, Agencia Nacional de Promoción Científica y Tecnológica, Argentina.

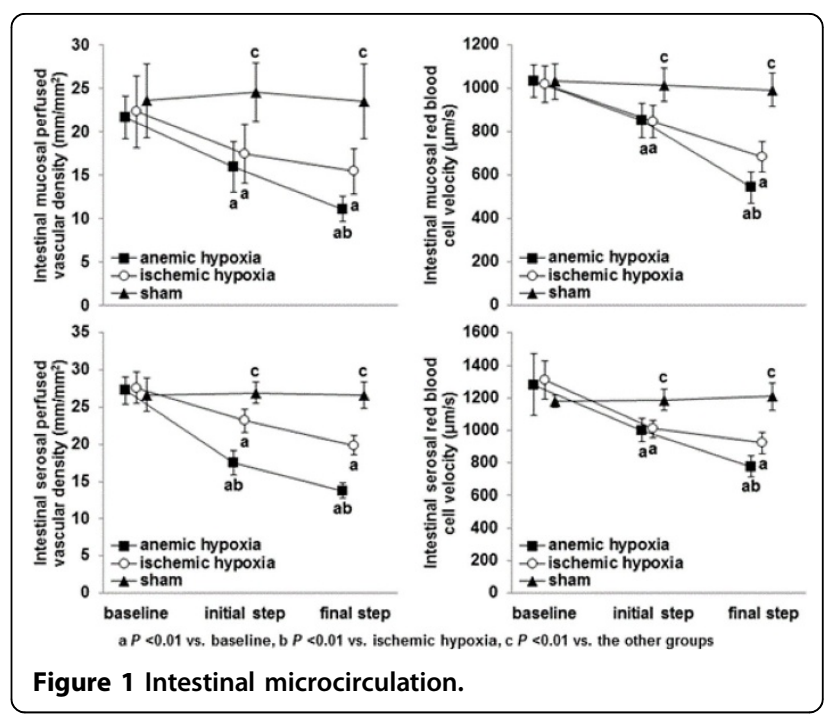




\section{Authors' details}

'Facultad de Ciencias Médicas, Universidad Nacional de La Plata, Cátedra de Farmacología Aplicada, La Plata, Argentina. ${ }^{2}$ Academic Medical Center, University of Amsterdam, Translational Physiology, Amsterdam, the

Netherlands.

Published: 1 October 2015

\section{Reference}

1. Dubin A, Estenssoro E, Murias G, Pozo MO, Sottile JP, Barán M, Piacentini $E_{\text {, }}$ Canales HS, Etcheverry G: Intramucosal-arterial $\mathrm{PCO}_{2}$ gradient does not reflect intestinal dysoxia in anemic hypoxia. J Trauma 2004, 57:1211-1217.

doi:10.1186/2197-425X-3-S1-A413

Cite this article as: Ferrara et al:: Microcirculatory alterations are more

severe in anemic than in ischemic hypoxia. Intensive Care Medicine

Experimental 2015 3(Suppl 1):A413.

\section{Submit your manuscript to a SpringerOpen ${ }^{\circ}$ journal and benefit from:}

- Convenient online submission

- Rigorous peer review

- Immediate publication on acceptance

- Open access: articles freely available online

- High visibility within the field

- Retaining the copyright to your article

Submit your next manuscript at $\gg$ springeropen.com 